\title{
A Neglected Resource in Community Development: Participation of Ethiopian Academics in the Development of their Communities
}

\author{
Worku Legesse ${ }^{1}$, Getnet Tadele ${ }^{2}$, Aynalem Adugna ${ }^{3} \&$ Helmut Kloos ${ }^{4}$ \\ ${ }^{1}$ Department of Civil and Environmental Engineering, University of Connecticut, Storrs, USA \\ ${ }^{2}$ Department of Sociology, Addis Ababa University, Addis Ababa, P.O. Box 150374, Ethiopia \\ ${ }^{3}$ Sonoma State University, Department of Geography, Environment, and Planning. 1801 East Cotati Ave, Rohnert \\ Park, CA 94928, USA \\ ${ }^{4}$ Retired from the Department of Geography, Addis Ababa University, Addis Ababa, Ethiopia; Research Associate, \\ Department of Epidemiology and Biostatistics, University of California, San Francisco CA. Current address: 2307 \\ N. Backer Ave., Fresno, CA 93703, USA \\ Correspondence: Helmut Kloos, 2307 N. Backer Ave., Fresno, CA 93703, USA. E-mail: helmutk@comcast.net
}

Received: April 11, 2018

doi:10.5539/enrr.v8n2p69
Accepted: May 2, 2018

Online Published: May 11, 2018

URL: https://doi.org/10.5539/enrr.v8n2p69

\begin{abstract}
This article examines three community development projects initiated by university educated individuals in or near their places of birth with the aim of presenting evidence that academics can be instrumental in contributing to development in their communities. The three projects used different approaches and resources. The project in Arya Jawi Kebele was developed and managed by a church-linked family association that aimed at broadly based development of this rural district guided by the theological principles of an Ethiopian evangelical church. The project in Kersole Village was initiated and managed by six university educated brothers, four of whom are currently living in the United States. Their primary objective was to help their family and secondly to improve livelihoods in the community. The project in the small town of Azena, conceived and fostered by a professor at Addis Ababa University, focused on the construction of a bridge over a river and several schools, with financial support mainly from several international NGOs. The academics' familiarity with the needs of and their acceptance by the communities facilitated interaction with local leaders, organizations and craftsmen during the planning and implementation processes and promoted community participation.
\end{abstract}

Keywords: academics as development agents, community development, infrastructure development, social and environmental services, Ethiopia

\section{Introduction}

Of the many agencies and agents involved in community development in Africa, least is known about the contribution of individual academics. Although public services and outreach activities have traditionally been major functions of universities, they have usually been carried out within the framework of specific curricula and programs (Unawenimana, 2014) with little information on individual academic entrepreneurs. Locally born individuals can be effective in fostering change in communities because of their familiarity with local needs, priorities, and culture, an advantage outside agents and organizations lack (Ozor \& Nwakwo, 2008). University-community partnerships may be jeopardized either because communities are dissatisfied with the delivery of services or communities consider universities to be outside organizations failing to embrace and integrate indigenous knowledge in development projects due to the difficulty of incorporating indigenous experiences and practices into their scientific paradigms (Baker, 2018). Many governments, NGOs, and community-based organizations also failed to foster community development (Botes \& van Rensburg, 2000; Ika, 2012).

Widespread disillusionment and high failure rates have been attributed to the use of one-size-fits-all approaches, lack of managerial capacity und understanding of culturally based community priorities and values, inadequate evaluation of results (Botes \& van Rensburg, 2000; Ika, 2012), and non-sustainability of projects after termination of donor support (Honadle \& VanSant, 1985; Sabbil \& Adam, 2015). Increasing evidence that poor people in developing countries are not passive subjects but primary actors and more capable of solving local problems than 
top-down development policies and programs (Fonchingong \& Foniong, 2003) indicates the need to identify all actors and entrepreneurs with intimate knowledge of local communities.

The Ethiopian government, indigenous and international faith-based organizations, non-government organizations, and universities have been main actors in community development in Ethiopia. The government of Haile Selassie developed an "integrated rural development" strategy to foster economic growth in different localities nation-wide. Its goal of developing small farms could not be achieved, largely due to inadequate peasant participation, unsustainable material, and financial resources, and lack of the necessary managerial capacity for cooperative framing (Tecle, 1974).

Many socioeconomic and political changes resulted from the 1974 revolution, during which the socialist Derg regime overthrew the imperial government of Haile Selassie. These changes included the nationalization of land; the formation of peasant associations, service cooperatives and agricultural producers' cooperatives; and the implementation of villagization, resettlement, and food-for-work programs. This situation resulted in an economic crisis and a decline in the living standard (Henze, 1993). These unstable conditions continue to hinder farmers' indigenous practices in soil conservation and sustainable agricultural practices (Cafer, Willis, Beyene, \& Mamo , 2015).

The present Ethiopian government started to operate in 2004 the Productive Safety Net Program (PSNP), the largest social safety net program in Africa. In 2015, this cash-for-work program benefited about 8 million drought-affected people, and similar numbers of people were served by the Emergency Food Aid Program. The PSNP has increasingly focused on community development to more effectively address socioeconomic and environmental problems. Nevertheless, major discrepancies in program benefits persist among communities, with the fewest improvements reported from poorer rural communities (Demissie \& Kasie, 2017; delete Filipsi et al.,2017).

Little is known about the impact of Ethiopian faith-based organizations on community development. The rapidly growing Ethiopian indigenous evangelical churches, the Ethiopian Evangelical Church Mekane Yesus (EECMY) and Kale Hiwot Church adopted a progressive, integrated approach to socioeconomic development that emphasizes holistic ministry (spiritual, bio-physical, and psycho-social growth) and initiated many community development projects (World Council of Churches, 2013). EEMCY continues to focus its programs on water supplies, sanitation, food security, savings/small credit and environmental conservation and rehabilitation (Arén, 1978; Ethiopian Evangelical Church Draft Plan, 2012).

International and local NGOs have been important agents of development in Ethiopia. They have been increasing broadening their program agenda from famine relief in recent years to address a wide range of environmental, poverty alleviation, food security, health, and education issues (Teka, 2000). The number of NGOs in Ethiopia peaked around 2,300 in 2007 but has since then declined due to government restrictions on their fundraising activities and operations (Chelkeba, 2011; International Center for-Not-for Profit-Law, 2009).

Universities in Ethiopia and other African countries are increasingly including community outreach activities in their curricula that address social development and capacity building (Warden, 2014; Wole, 2011; Zeelen, 2012). The provision of community service constitutes an integral part of university education in South Africa, peer counselling has been practiced by university students in rural communities in Zambia, where and workshops on community service programs involving teachers and school librarians are held by all state universities (Community Outreach Activities, n.d.). In Ethiopia, university outreach and service programs in rural communities dates back to the famines in the 1970s, when university students and faculty supported famine victims through a university-sponsored famine relief fund. The Derg regime forcefully enlisted university students to carry out the Zematcha rural development campaign with the main objective of educating peasants about socialism. In recent years, Ethiopian universities have increasingly instituted community outreach programs, sending students to carry out health and sanitation projects. The Ethiopian Institute of Water Resources of Addis Ababa University and the environmental health departments all other Ethiopian universities are mandated to send undergraduate students to urban and rural communities to address water and sanitation problems, construct latrines, and develop new water supply technology (Ethiopian Institute of Water Resources, 2017), and the curricula of schools of public health require master students to carry out field work on urgent health problems (Tegene, Assefa, Tessema \& Kebede, 2000). Little is known about the impact of these programs on community development. A drawback of university-based community outreach programs was reported from Addis Ababa, where academics were considered to be outsiders and project implementation was therefore jeopardized (Yeneabat \& Butterfield, 2012). 
No information has been published (to our knowledge) on outreach activities by individual African academics in their home communities, although Warden (2014) reported that some Ghanaian students pursued development opportunities in their communities.

Increasing numbers of the estimated 1-2 million Ethiopians in the diaspora are establishing businesses and invest in Ethiopia, mostly in Addis Ababa. To encourage return migration, the government has created administrative offices dealing with the diaspora and issued nearly 2000 investment licenses to diaspora Ethiopians in 2005 alone (Chacko \& Gebre, 2009; Kuschminder \& Siegel, 2011). However, no published information appears to exists on voluntary work and small-scale investing by academics in their home communities. This article examines the role of Ethiopian academics in the development and implementation of infrastructure and social programs in their home communities.

\section{Methods}

The authors of this article are current or former academics from Addis Ababa University and Jimma University who helped to develop social service and infrastructure projects independent of one another in the three communities of Kersole Village, Arya Jawa Kebele (kebeles are the smallest administrative unit in Ethiopia), and Azena Town (Figure 1). The three Ethiopian authors were born in or near these communities. The information was collected by the authors and their associates over periods ranging from 8 years (Azena) to 12 years (Kersole) through interviews and personal observation using notebooks and cell phones. Although the projects were of different sizes and durations, addressed different problems, and used different strategies, they all were headed by one or several individuals who played central roles in defining project objectives, generating the necessary resources, implementing the projects, and evaluating the results. This article presents information on the study communities and the objectives, implementation, and evaluation of each project.

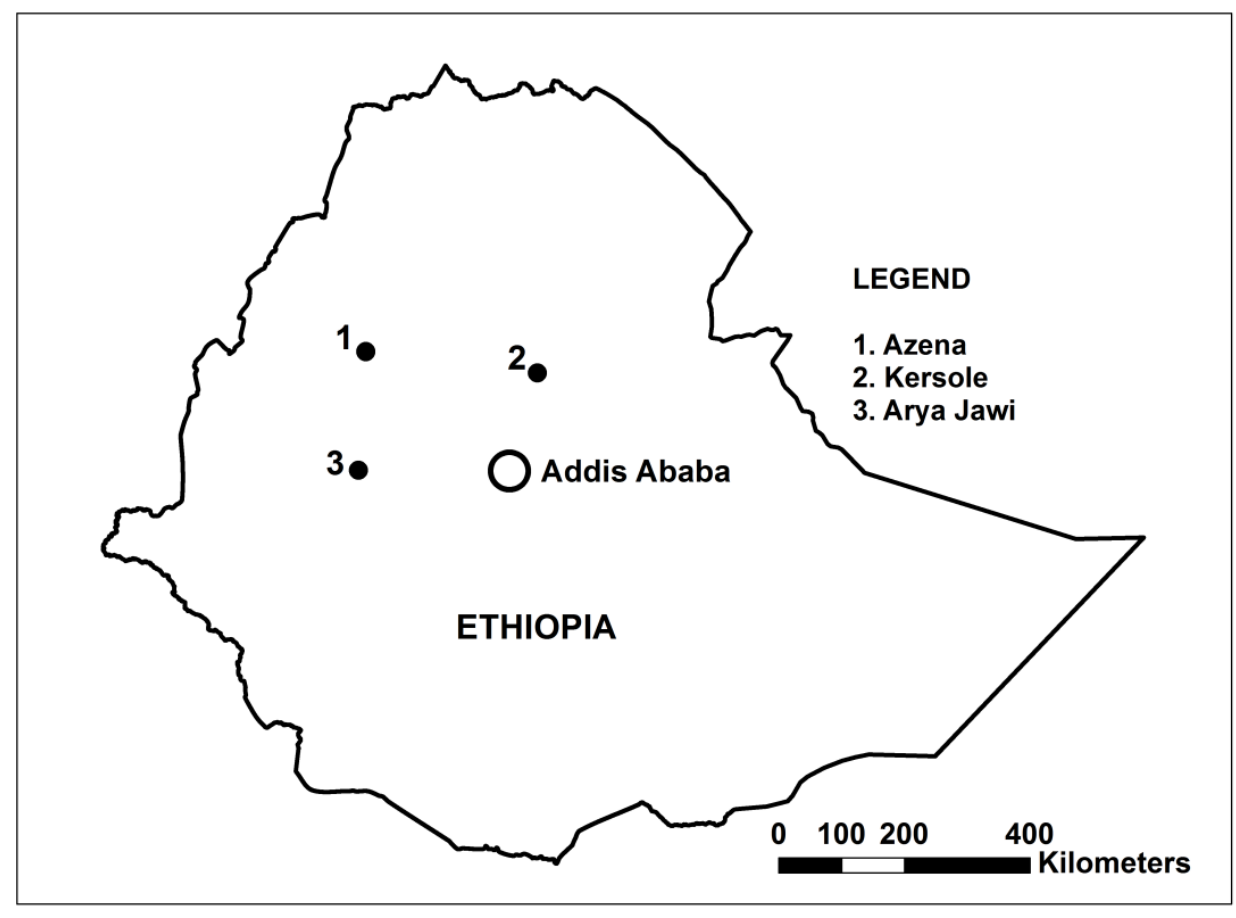

Figure 1. Location of the three study communities

\section{Results}

\subsection{Arya Jawi}

Arya Jawi is a rural kebele located $10 \mathrm{~km}$ east of Nekemte Town in Wayu Tuka Woreda (District), Oromia Regional State, and has a population of about 3,000, nearly all of them of the Oromo ethnic group. Most of them are engaged in subsistence agriculture, cultivating teff (Eragrostis teff), sorghum, and maize cultivation, and 
raising livestock. This humid highland area is spared from drought in most years but the rural communities have to deal with chronic poverty and environmental degradation.

\subsubsection{The Buraka Family Committee}

Aynalem Adugna and his relative Kebebew Daka, a senior community leader, founded the Buraka Family Committee in 2000 with the objective of initiating, supporting, and managing the Arya Jawi community development project through the church. The project has been supported by the Ethiopian Evangelical Church Mekane Yesus office in Addis Ababa, which assigned a pastor to the church. Many Buraka descendants who obtained higher education decided to give back to the community a fraction of what was invested in them. Most development activities are being funded by members of the Buraka Family Committee and several committed family members in Ethiopia and in the diaspora. The Committee channels assistance to the community through the church.

\subsubsection{The Religious Base}

Northern European Presbyterian and Lutheran missionaries started evangelical missions in Wollega Region at the end of the $19^{\text {th }}$ century and subsequently in other parts of western Ethiopia. In 1959, EEMCY was recognized by the government as a state church. In 2009, 58.8\% of the 63,000 residents of Wayu Tuka Woreda were Protestants, $28.7 \%$ belonged to the Ethiopian Orthodox Tewahedo Church, 9.1\% were Catholics, 0.4 percent were Moslems, and only 38 individuals considered themselves to be members of indigenous religions (Arén, 1978, FDRE, 2008). This small number appears to be due to the reluctance of many people to identify with Oromo traditional religion, whose ritual practices, beliefs, and culture have been suppressed for several centuries (World Council of Churches, 2006). Arya Jawi Church is accommodating traditional Oromo religious beliefs besides following its mission of teaching the gospel of Christ.

The Buraka Family Committee identified the following nine developmental challenges that are currently being addressed in phases: child education, female and child health, poverty, environmental degradation, declining agricultural production, gender inequity, child rearing practices, community self-help, and transportation problems The committee plans to develop a healthy and prosperous community taking good care of its human and environmental resources based on EEMCY theology. These goals are to be achieved by raising awareness in the community and mobilizing resources based on the principles of holistic development and self-reliance.

No major development activities were carried out in Arya Jawi Kebele prior to the founding of the Buraka Family Committee, with the exception of the construction of an elementary school by members of Kebebew Daka's family. All of the above programs were first introduced to the community by the committee.

Since 2000, the Buraka Family Committee and the church have closely cooperated to achieve the above goals. The pastor of the church has played a key role in the administration of the community development projects based on annual plans of action. Emphasis has been given to the mobilization of human and natural resources that will expedite work on the various programs and address emerging challenges. The head of the committee or his representative visit Arya Jawi Kebele every year to monitor and assess the progress of the programs and assist the community. Six spiritual and community development programs were carried out in between 2014 and 2016, discussed below.

\subsubsection{Spiritual and Related Activities}

More than 350 congregation members and 83 Sunday school attendants attended religious services in 2015. Youth activities, women's spiritual activities, outreach services, training/capacity building activities, and leadership development activities were given high priority. These activities, carried out under the Mekane Yesus Church's motto "serving the whole person", promoted community collaboration and participation. Issues of helping the needy and service to others are discussed during the weekly church services.

\subsubsection{Women Empowerment and Economic Development}

The savings and credit program for women aims to increase mutual support and collective saving. Fifty-two women had participated in the program by 2012. These women purchased livestock, clothes, and shoes with 500 Birr (25 \$US) each had borrowed. By 2013, they had collectively earned over 87,000 Birr. Participants who owned no livestock at the start of the program now have poultry, goats and cows or oxen, some of which households fatten and sell in the open markets. These animals contribute substantially to household food security and overall wellbeing of families. Children, for example, now attend church with better garments and shoes and are said to be in better physical health. Other income generating projects initiated by the church include bee-keeping and coffee tree cultivation. Each group member saves 10 Birr weekly. These savings are deposited after each monthly 
meeting of the group in a collective savings account in a bank and most of the savings are distributed to new cooperative members for further income generation.

\subsubsection{Student Sponsorship Program}

The student sponsorship program addresses the needs of children who have completed Grade six or eight but find it difficult to pursue education in higher grades due to poverty. On average, 10 students receive financial assistance annually from the Buraka Family Committee. During the 2014/2015 academic year, eight of these students graduated from elementary and high schools and one student enrolled in a university. The committee anticipates the program will produce leaders who will lead and contribute to Arya Jawi's community development aspirations in the future.

\subsubsection{Road Construction}

Arya Jawi Church considers motorized transportation to be vital to communication with urban communities. Arya Jawi Kebele was inaccessible by motor vehicle until recently. The first dry-weather road was constructed to Nekemte Town with community mobilization and financial contributions of family members. Building this road was costly and challenging because of the absence of building materials such as sand and stones in the kebele and the need to acquire them from distant localities. The church can now bring in building materials and other goods during the dry season on the dirt road the community built, although the rugged topography remains a major problem.

\subsubsection{Environmental Protection and Development}

The environment and natural resources of Arya Jawi Kebele, on which the inhabitants depend for their livelihood, have been increasingly impacted by poverty and overpopulation. These and other social as well as demographic factors, rather than lack of environmental awareness, may be the major driving forces in the degradation of the natural environment in Arya Jawi as the Oromo have traditionally protected the natural environment in manners prescribed by the indigenous Oromo religion (Kelbessa, 2001). Some women haul firewood and occasionally charcoal, which is sold predominantly by men in Nekemte to earn extra income. Wood is needed also for construction and fences, and forests continue to be cleared for farming.

Soil erosion and land degradation are significant problems in Arya Jawi Kebele due to population increase and increasing intensification of agriculture, including overgrazing. Cattle are kept in enclosures on communal grazing grounds for overnight deposition of dung. Weekly moving of the corrals permits gradual fertilization of the land for cultivation and constitutes a manure management system that is more beneficial for agricultural production than the systems in other Ethiopian highland areas (Kelbessa, 2001).

According to living witnesses, Arya Jawi Kebele was covered with dense forests that supported many wild animals of different species some 50 years ago. After 2008, measures were taken by Arya Jawi Church to reverse the degradation of the natural environment. This program I includes raising seedlings in nurseries around the church for reforestation, protecting flora and fauna that are becoming scarce in the area, educating the community about the importance of the natural environment in sustaining economic activities, making the church a demonstration and practice site for tree planting, and constructing hand-dug wells to water seed beds and plants during the dry season.

\subsubsection{Awareness Raising Against Harmful Traditional Practices}

Harmful traditional practices, especially those affecting women and children, are causes for concern. These practices are rooted in poverty, gender inequity and cultural preferences. Most sick people attend hospitals and clinics only as a last resort in late stages of illness or after accidents. The absence of a health center in Arya Jawi Kebele promotes the use of traditional medicine. There is also concern over child-rearing practices such as feeding children nutritionally unbalanced diets. Experts from sectoral woreda offices (health, agriculture, and social services) regularly visit the Arya Jawi community for awareness raising and capacity building activities to facilitate healthy child rearing practices and increase the use of health services in nearby communities.

The most important achievements of the community development program, according to the Buraka Family Committee, are tangible attitudinal and behavioral changes away from apathy and non-participation in community activities toward increased awareness of the prevailing socioeconomic and environmental needs and active and committed participation in community affairs fostering self-help and self-reliance.

\subsubsection{Challenges}

Of the various programs discussed above, environmental conservation is least likely to generate positive changes in the short term, primarily due to persisting poverty and lack of alternative income sources in this agricultural 
community. Environmental degradation and decreasing carrying capacity of the land may be controlled and reversed with further progress in socioeconomic development and diversification of Arya Jawa's economic base.

Much work also remains to be done with respect to parents' attitudes toward the education of their children, as many parents attach little value to education because they depend on child labor for herding small animals, running errands, fetching water, and performing other domestic activities. There is some evidence that nonattendance of Sunday school also jeopardizes the primary education of children. Part of the education problem is the lack of qualified Sunday school teachers.

The project suffered a big setback in 2014, when the pastor, a strong proponent of community development activities, left the church. Finding a replacement has been difficult due to the small number of educated persons and lack of leadership skills in the community. Since the departure of the pastor, the Buraka Family Committee has had difficulty monitoring the project in the absence of progress reports from the church. Similar issues with and community mobilization for the ministry are now significant problems in a number of EECMY synods in Ethiopia. Another concern is the rise of secularism, which threatens to weaken the social fabric and community bonds as well as communal cooperation in the project, a problem reported since the revolution in the mid - 1970s (Adejumobi, 2005).

This discussion indicates that the Arya Jawi community has developed a strong sense of self-reliance and is laying the foundation for a better future. The program was evaluated by woreda officials in November 2012. These experts were impressed with the performance of the program and sent a letter of appreciation to the church in which they described the program as a model for other churches.

\subsection{Kersole Village}

Growing up under economic hardship in a rural village in the drought-prone Wollo Highlands, Worku Mulat and his five brothers were determined at an early age to escape poverty through higher education. They all obtained college degrees in Africa, Europe, or the United States and periodically returned to Kersole Village in recent years to implement a community development project. Kersole Village is located on a plateau above 2.600 meters elevation in Jama Woreda, South Wollo Zone. For the majority of its approximately 350 residents, life has changed little during the three decades since the brothers left the area. Non-government organizations are reluctant to go into this remote area due to lack of all-weather roads. Recurring drought and periodic frost render rainfed agriculture highly vulnerable to the vagaries of the weather. Thousands of people died during the famines in the 1970s and 1980s and during the 1999/2000 drought, when half of South Wollo's population depended on food aid (Little, 2008). Subsistence rainfed agriculture on dwindling plots of degraded and eroded land and lack of income diversity can no longer sustain the increasing population. Food insecurity is similarly severe in Jama Woreda, where illiteracy rates are above $70 \%$ and a high proportion of households are headed by females, who are more vulnerable to poverty than men (World Bank, 2017). The high plateau around Kersole lacks surface water except for a few distant springs and an intermittent stream with water too silty for human use. Nearly all households practice mixed rainfed agriculture involving the staples wheat, barley, and teff and raise livestock, mostly cattle, sheep, and goats, which can no longer support the growing population. As a result, adult men migrate seasonally to work as laborers on commercial farms and many parents are sending some of their children to work in nearby towns and in the Middle East.

\subsubsection{Family History and Planning the Project}

The Mulat brothers grew up in a large extended family in Kersole Village. The family eked out a living as share croppers in the 1960s and 1970s. Plots became even smaller during the land reform in 1975 due to frequent land distribution during the land reform. The parents realized that the large family could not be sustained on the small plots and decided to send all six brothers to schools.

While growing up in this precarious environment the Mulat brothers developed a strong desire for higher education and eventually helping their parents and community. In 2005, they decided to launch a livelihood improvement project in Kersole Village. Both Lakew and Yirga travelled to Ethiopia to make feasibility assessments and identify potential projects that could be implemented. In order to generate the required financial resources, the Mulat brothers established a nonprofit organization in the United States. Legal requirements to operate this NGO in Ethiopia became an insurmountable obstacle, prompting them to use family-based resources instead. In 2005, the brothers decided to first build a church in Kersole Village and then connect the village to the electric grid and develop a safe water supply. 


\subsubsection{Building the Church}

The people of Kersole Village had entertained hopes for many years of building a church to better meet the religious and social needs of the community. Concrete plans were made in 2005 under the leadership of community leaders, the authors and their immediate families. The land for building the church was donated by the parents of the brothers. Besides Worku and his brothers, an engineer; a nurse and several other people born in Kersole made donations for building the church.

Since the completion of the church, the residents of Kersole no longer have to carry the bodies of people who died to distant places for burial and social events and religious ceremonies are now held in the new church. In addition, more Sunday school children now receive church education and adults bring food and drink to the church to serve lunch to priests and the congregation after church services. These and other social and religious functions can now be held throughout the year in contrast to the past, when swollen rivers during the rainy season often precluded overland travel to far-away churches.

\subsubsection{Water Supply and Irrigation Project}

Potable water has always been scarce and considered a precious resource in Kersole Village but its use continues to increase. Collecting water for domestic purposes, traditionally done by women and girls, remains one of the most important household duties in Kersole and other communities in Jama Woreda. In the past, household water consumption was regulated by the community to balance demand and the limited supply. The major water uses in a typical household include drinking (humans and animals), cooking, bathing, and cloth washing. During the rainy season, several households supplemented their water supplies with water collected from corrugated metal roofs by using gutters and collecting containers. Prior to our project, all domestic water had to be fetched from distant unprotected springs or rivers that were not safe for human consumption.

The brothers installed a pump on top of a raised cemented stone platform and used a long pipe that freely rotated to supply water designated separately for animal watering and human water at the collection points. In an effort to improve food production in Kersole Village, they launched a small- scale irrigation project on a 0.1 ha plot their family owned. In order to satisfy irrigation and household needs, a multipurpose hand-dug well was constructed in 2010. Local masonry workers trained through the woreda agricultural extension program manually dug a shallow well. A hand pump was installed and the water was pumped to two water storage tanks, one provided by Jama Woreda Agricultural Extension Office. The well has an estimated flow rate of about 25 liters per minute and meets the domestic water needs of village households and their animals and provides water for irrigating a vegetable garden and planted trees. Cabbage, garlic, and other vegetables have been grown successfully for home use and the market. This is a remarkable success, considering that this is the first attempt to implement an irrigation project in the village. In the beginning, all residents of Kersole were allowed access to the water from this well. However, some failed to comply with the request to contribute labor to dig additional wells and the woreda office asked the operators of the well to lock this water source to indirectly force households to develop their own wells through woreda-assisted projects.

\subsubsection{Sanitation Project}

A major challenge in rural Ethiopian communities has been the provision of functional toilets and ensuring their proper use and maintenance to reduce disease risk and to ensure the dignity of the people. The Mulat brothers constructed a flush toilet equipped with a shower and running tap water for hand washing for their family and to inspire others to build their own toilets. Although open defecation was the norm until the 1980s, most households currently use pit latrines. However, their poor construction and maintenance discourage many households from using them. The new toilet facility is used by all residents in the neighborhood, corroborating the findings of many studies that clean, safe toilets are crucial in sanitary interventions (Adane, Mengistie, Kloos, Medhin, \& Mulat 2017).

\subsubsection{Nursery, Silviculture, Horticulture, and Apiculture Project}

Considerable income has been generated and household expenditures reduced through the production of vegetables, nursery seedlings, and honey. The brothers developed an irrigated nursery including silviculture, horticulture, and apiculture subprojects on their family's plot with the hope that it will serve as a demonstration ground for other families. Although the woreda agricultural extension bureau encouraged other households to replicate this project, none had done so by 2016 due to high costs. Nevertheless, this self-help project may serve as an entry point to identify, formulate, and implement other income diversification projects that enable farmers to take advantage of woreda and international assistance programs in utilizing improved water management technologies and new horticultural methods. 
In the past, there were few trees in Kersole. The Mulat brothers recently planted five species of trees from seedlings, most of them good sources of fuel wood, animal feed, and food for bees. These include three species of Acacia and two species of Eucalyptus. The planting of trees encouraged the development of bee keeping, an unintended benefit of this program. Traditional apiculture has a long history in Ethiopia and continues to be practiced in South Wollo. The crucial role of reforestation in maintaining ecosystems, providing fuel wood for cooking, reducing soil erosion and providing other ecosystem services has been described for various parts of the Ethiopian highlands (Bishaw, 2001; Bishaw \& Asfaw, 2010; Negewo, Ewnetu, \& Tesfaye, 2006).

\subsubsection{Kiosk Project}

The objectives of opening the first kiosk in Kersole in 2013 were to increase the availability of common manufactured household goods, provide a local outlet for farm produce that could benefit both households and the wider community, and supplement household incomes. The kiosk project provides supplemental household income, increases access to low-cost household goods, and increases food security throughout the year. These various benefits prompted another two other households to open kiosks, including a mother of six who opened a kiosk as an off-farm activity. The potential domino effect of this income-generating activity may also reduce outmigration of young people to nearby towns, cities, and even to the Middle East and Europe.

\subsubsection{Electricity Grid Connection}

A World Bank (2015) report shows that $73.4 \%$ of the Ethiopian population had no access to electricity in 2012 , with even lower coverage in remote rural areas. Ensuring access to electricity in rural households is a daunting task from the economic as well as the administrative perspective. Nevertheless, that World Bank safety net report noted that access to the grid provides numerous opportunities for socioeconomic development, ranging from a healthier indoor environment to the use of electric light, household appliances, and machines.

The project manager, one of the brothers (Zewdu), negotiated with the woreda authorities to secure the delivery of a transformer and electric supply to his parents' house in 2014, a nearby household and the church. Many other households are considering connecting to the electric net, which is fed by low cost hydropower. Through this self-help effort, Kersole Village is now the first village in Jama Woreda to be connected to the electric grid. Major benefits coming from the electricity are the installation of a mobile phone charging facility and two electric flour mills. Satellite TV has also become accessible.

\subsubsection{Biogas Plant}

In early 2018, Zewdu initiated and managed the construction of a biogas plant through Jama Woreda Agricultural Extension Office, which assists any household able to pay $40 \%$ of the cost as part of the National Biogas Program of Ethiopia. Trained workers from that woreda office helped with the installation and optimal operation of the plant. In addition to providing heat for cooking and light, biogas plants can reduce indoor air pollution, produce bio slurry as fertilizer, reduce the use of fuelwood, and thus reduce deforestation (Berhe, Tesfahuney, Desta, \& Mekonnen 2017).

\subsubsection{Mobile Phone Charging Facility}

The Mulat family constructed a hut with a charging facility that can handle up to 50 cell phones at a time. The cost of charging mobile phones in this facility is less than in towns and, more important, the facility eliminates the need to travel to distant towns to recharge phones. Farmers from nearby villages are now recharging their cell phones daily, allowing them to monitor market prices of agricultural goods for cost-effective buying and selling.

\subsubsection{Flour Mill Project}

Diesel flour mills existed in Jama Woreda for decades but farmers had to travel long distances to those mills, causing many families to continue to grind their flour manually using stone and pestle. The Mulat brothers installed two electric flour mills in 2011 and started operating them in 2013. Since their connection to the electric grid, the two mills have been operating long hours each day to process the large amount of grain they receive. The location of Kersole near a hydropower source and away from major towns precludes power outages or rationing. Farmers are coming to use the mills in Kersole even from areas close to towns because of their nearness and lower milling prices. Two permanent and three temporary workers were employed by the community in 2015 to operate the mills. Economic performance of this project so far is very encouraging and promises to be sustainable. The benefits of such a small business in a rural setting are far reaching. It brings grain milling service closer to villagers, creating free time for other important socioeconomic activities and thus increasing food security. 


\subsubsection{Achievements and Challenges}

This community development project provided Kersole and to some extent also surrounding communities with spiritual, water, sanitation and technological services and food resources more effectively, more cheaply and appropriately through family self-help endeavors than the typical government and locally scarce NGO programs. The project also provided employment to several residents. The time saved from some of the interventions is enormous, allowing time for other domestic and agricultural activities. The project has provided employment for several permanent and part-time workers and may be expected to provide more job opportunities. Due to increased food security and higher incomes, the Mulat family is no longer dependent on remittances from the four sons who live abroad, and the wider community is benefiting as well.

Ensuring the project's sustainability and its potential for expansion to nearby communities carries a number of challenges. Bureaucratic delays in obtaining permits and other hurdles are challenges that need to be taken into account in planning rural development projects. For instance, it took more than a year to receive approval and install the connection to the electric grid. Another challenge was the tenuous collaboration among family members running the project. Family members other than the six brothers tended to divide the various projects and run them individually, the outcome of which impeded their smooth operation and profitability.

At the community level, the observed resistance to digging wells, notwithstanding the fact that the woreda bureau was willing to provide considerable subsidy and expertise, constitutes another weakness in collaboration that may be due to lack of community leadership. These observations corroborate the finding by Negatu (2004) that culturally embodied traditional values and attitudes toward time management, capital accumulation, and profit often negatively affect livelihood activities and the management of households in South Wollo Zone. Nevertheless, the information and experiences gained through this family-based project sheds new light on best practices for Ethiopians interested in helping their rural communities

\subsection{Azena Town}

Azena Town is located in Anekesha Gugsa Woreda, in Agew Awi Zone, Amhara Regional State. This woreda had a population of 226,004 in the 2007 census, 94.5\% of whom lived in rural areas (FDRE, 2008). Getnet Tadele grew up in the rural village of Dogen near Azena Town. During his childhood he became aware of two major problems the people of the woreda faced, namely the threat of drowning when crossing the local Ayo River and the lack of access to elementary and secondary schools within a reasonable distance. After moving to Addis Ababa to obtain his university education, Getnet decided to help Azena residents to safely cross the Ayo River and obtain better access to education. He has been working with NGOs and the community of Azena since 2006 to address these problems by facilitating the construction of a bridge and several schools. Getnet played a key role in mobilizing the community, serving as a liaison between the community and the NGOs and facilitating the implementation of the projects. This section describes the implementation process, impacts, challenges, and lessons learned from these infrastructure projects.

\subsection{Bridge Project}

Building a bridge across the Ayo River was intended to reduce drownings, reduce loss of livestock and goods in the river, solve many problems hampering economic development and facilitate the provision of social and health services in and around Azena Town. The bridge project was beyond the financial and technical capacity of the Anekesha Gugsa Woreda and Azena community. Getnet contacted the then-country representative (CR) of the NGO Partners in the Horn of Africa (PiHA) in 2008. Subsequent discussions between the CR and the NGO executive director and an exploratory visit to the Ayo River by the CR, indicated that an estimated 60,000 villagers on both sides of the river crossed the river during the main rainy season and an estimated 11,000 people every Saturday to go to the market in Azena Town, the only market in the area; as many as 600 children had to cross the river daily to attend the only secondary school (Grades 9 and 10) in Azena Town; many students missed exams and repeated grades when the river was high, and a considerable number of students drowned; and pregnant women in labor and people with serious illnesses could not access medical services in towns on the other side of the Ayo River. Further, attending burial ceremonies and other important church services, visiting family members and friends, and accessing government services such as courts and police stations was often impossible during the rainy season. More than a dozen people drowned each year trying to cross the Ayo River and additional lives were lost due to the barrier this river posed to transporting patients to medical care.

Getnet facilitated discussions between the NGO and the community representatives and local government officials on issues such as bridge design, cost sharing, and the most suitable time for construction (when farmers were free to provide labor and materials and the water was low). Members of surrounding communities participated in site selection and the Council of the Anekesha Gugsa Woreda Administration assigned a focal person to mobilize the 
community and monitor the progress of the project. While most of the cost of constructing this bridge was covered by the NGO, the community participated in different ways. It contributed money and donated locally available materials (rocks and sand) and unskilled labor (villagers provided free labor). With local engineering support, a 48 meter span steel bridge was built and inaugurated in May 2009, before the main rainy season. According to local people, there has not been a single loss of human life in the communities on both sides of the river or loss of goods since the completion of the bridge.

The bridge helped increase school enrolment and improved school attendance and participation but failed to ensure the progression of students to high school and beyond. This situation prompted Getnet to become involved in the school projects described below.

\subsection{School Projects}

\subsubsection{Upgrading Azena Elementary School to a High School}

Until 2006, Anekesha Gugsa Woreda had only one secondary school in its capital, Gimjabet Town. Lack of a high school in Azena Town meant that students had to go to Gimjabet to attend high school. Transportation and living costs were unaffordable to many parents and the majority of the male students had to drop out and become subsistence farmers and females had to leave school to help with domestic chores before marrying early.

Because of sustained demand from the residents of the Azena community and through mobilization of resources from the community, the only elementary school in Azena was upgraded to a high school by construction of two buildings with 10 classrooms in 2006. Although the elementary school was upgraded to a high school through the efforts of the Azena community and Grades 9 and 10 were opened, the school lacked essential facilities, including a library and natural science laboratories. This situation prompted the Amhara Regional Education Bureau to issue a warning that it would shut the school down in September 2009 unless those facilities were made available. Getnet then worked with the community to ensure that many girls and boys retained access to a quality high school education close to home. PiHA supported the construction and equipping of a library and two laboratory buildings. The library enabled students to do their homework and prepare for examinations, and the laboratories provided them with natural science education essential for college/university entrance. Access to the library and laboratory facilities also encouraged student participation, improved academic performance and reduced the dropout rate.

\subsubsection{Renovation of the Elementary School and Building a Library and Toilet Facilities}

Azena High School described above was built on the premises of the former Azena Primary School. In order to vacate some buildings and to cope with the shortage of classrooms, the community raised some funds and built five mud blocks with 22 classrooms at another location.

In 2010, the school had classes for Grades 1-8 and there were 2,224 students, of whom 1,114 (50.1\%) were females. In spite of the large and growing student body, the poor infrastructure and absence of other facilities, including a library, and deficiencies in the building structures and furnishings were bottlenecks to delivering quality education. Due to shortage of funds, the classrooms lacked doors, windows, and concrete floors as well as student desks. The dirt floors made cleaning difficult and resulted in dusty conditions that exposed children to respiratory and other infections. Further, the mud walls of the classrooms had been eroded by rain. All of the classrooms lacked desks and chairs, forcing children to sit on the dusty floor or wooden logs, adding to the disease and accident risks inherent in these substandard structures. The existing latrines in the elementary school were poorly maintained and the students found it risky to use them. Boys often used the open field instead. Girls, who need more privacy and who can't use the open field for obvious reasons, found it hard to attend classes, especially during their menstruation periods. The lack of safe and proper latrines was reportedly one of the main causes of low class attendance among girl students.

It is against the above background that Getnet worked with the community and PiHA to renovate and furnish five classroom blocks (22 classrooms), construct and furnish a new library and supply books, and construct a new latrine connected to a water system and with a handwashing basin. To achieve these objectives and in order to create a safer environment more conducive to teaching and learning and increase the school's enrolment capacity, the five sub-standard classroom blocks were rehabilitated and furnished with combined desks. The renovation work also included installing new ceilings, doors, windows, and a concrete floor. The outside walls were plastered with cement and pavement and drainage pipes were installed.

A new cement block library was constructed and furnished with tables and chairs for students and the librarian. This made it possible for up to 90 students to read at a time in addition to those who borrow books to read at home. New latrines with water flush and hand washing basins were also constructed. Of the total cost of Birr 1.83 million, the community contributed Birr 0.45 million and PiHA 1.39 million Birr and provided an experienced construction 
consultant who drew up a cost-effective design. The new school provides students with adequate seating, working, and recreation space. An estimated 2,224 students benefited from the improved facilities in 2017.

\subsubsection{Upgrading the General Secondary School to a Senior Secondary/Preparatory School}

Recently the education system in Ethiopia was vastly expanded. The pre- university education system now consists of different tiers. Primary school education comprises two cycles, Grades 1 to 4 and Grades 5 to 8 . Secondary schools have two cycles, Grades 9 to 10 and Grades 11 to 12 . Grades 11 to 12 are often referred to as senior secondary or preparatory school for university.

The absence of a preparatory school in Azena Town resulted in the drop-out of an estimated $40 \%$ of students who could have attended preparatory school and beyond but lacked the economic means to continue their education in another town. Students from Azena were required to find accommodations in Gimjabet and other towns, a task unaffordable for most families and one that presented additional socio-cultural barriers for girls. Families relying on subsistence farming also relied on the labor children provided in the household and on the farm after school hours.

The Azena community decided to upgrade the general secondary school to a preparatory school so children from destitute families could finish Grade 12. The woreda and zonal education departments approved the project and agreed to assign teachers if and when the community could build, furnish, and equip the required facilities. Getnet had to look for partner charities while encouraging the community to raise funds to make a preparatory school possible. PiHA, together with the NGO Live to Give Charitable Trust, agreed to support the project and work with the community and the local government. With the support from PiHA, the community built and furnished eight classrooms in two cement block buildings. Two ICT (information, communication, technology) rooms/computer labs and one technical drawing room were also built and furnished. With support from Live to Give Charitable Trust, Azena community bought eight desktop computers and one laptop for the computer lab and 200 copies of reference, fiction, and self-help books. Most importantly, the community renovated eight classrooms as required by the zonal education department to permit the operation of the preparatory school. The total cost of the construction was 2.0 million Birr, of which 0.6 million Birr were supplied by the community and the remaining 1.4 million by PiHA.

Preparatory schools in Ethiopia are the gateway to university education and the construction of the Azena Preparatory School constitutes a major step forward to promoting high school education in the area, especially for poor and female students. It also reduces the economic burden and emotional stress on parents and children from the departure of students to far-away schools.

\subsubsection{New Elementary School in Azena Town}

In November 2015, Getnet was able to secure funding from Francis G. Coso Foundation (FGCF) and Live to Give for the construction of a new elementary school in Azena which was inaugurated in October 2016. This school took pressure off the existing Azena Elementary School, which accommodated more than 2,400 students in 2015. After completing the construction of buildings, FGCF is currently working to increase net enrolment and reduce delayed enrolment and improve attendance, participation, achievement, and grade progression as well as acquisition of self-directed and lifelong learning skills in this new school.

\subsubsection{Challenges and Lessons Learned}

The four projects generated many benefits but the project managers encountered many challenges, particularly during the construction of the bridge. The community could not fulfil its commitment to provide labor for seven days (20 people per day) because farmers were busy with seasonal chores, a situation that was exacerbated by lack of adequate administrative support. Based on this experience the project managers decided to ask the community to make its contribution in cash and deposit the same in PiHA's and FGCF's accounts before the opening of bids for subsequent projects. This arrangement proved to be more effective, allowing the school projects to be completed more quickly. We also established a committee made up of community members to be in charge of each project rather than having one civil servant represent the community and the government during the construction of the bridge. This revealed that working with communities rather than for communities is more likely to ensure ownership, innovative approaches, and sustainability, consistent with the community assets approach to community development.

Overall, each project had its unique challenges. Nevertheless, with persistent reminders and follow-ups from the community, the NGOs and Getnet, and allowing for the expected delays for projects in Ethiopia, all five projects were completed in a good manner and a reasonable time. 


\section{Discussion}

All three community development projects were successful in that they achieved their objectives by virtue of the authors having intimate knowledge of the needs, priorities, and culture of the target communities because they were born in those communities. In addition, the authors' leadership abilities, their ability to obtain funding from outside sources, and their ability to work with community leaders and organizations, were all enhanced by their university education. These and other best practices in project development ensured that the projects were satisfactorily completed and are contributing to improving the livelihoods of the local population. The design and implementation of all three projects under the leadership and guidance of locally born academics ensured that objectives, targets, community inputs, and time lines were adapted to the needs and resources of the communities. Similarly, the authors had either developed adequate project capacity over the years or were able to improvise management practices after the initiation of projects. These achievements corroborate results of studies examining the contribution of capable leadership to sustainable community development (Udensi, Daasi \& Igbara, 2012) and questions the conclusion by Geith and Vignare (2013) that African university professors are urban-born and unlikely to be actively engaged in rural development projects. In Ethiopia, most junior faculty members were born in rural areas were able to obtain their university education following the revolution in the 1970s.

The types of service and infrastructure projects undertaken and the different approaches used by the authors to achieve their objectives were largely based on local needs but also the availability of financial and material resources in the communities and from outside sources and the type of community participation and management. In this setting, adequate community participation could be generated notwithstanding minor episodes of weak participation in well water development in Kersole and bridge construction in Azena. Thus, the common pitfalls of community development projects undertaken by outside agencies, including national governments and local and international NGOs (Botes @ van Rensburg, 2000; Ika, 2012), could be avoided.

In Arya Jawi Kebele, engagement of the Buraka Family Committee and Council as the organizational and managerial body enabled the various social, infrastructure and environmental programs to be conducted. The delegation of the planning, financing, and implementation responsibilities to the two committees functioning under the umbrella of the Arya Jawi EECMY ensured broad community support. The project has become nearly self-sustaining in the last few years through the financial contributions of Arya Jawi EEMCY and Buraka family members and the mobilization of community members for self-help and self-reliance. These achievements are corroborated by outcomes of projects by community-based organizations elsewhere, although Okeke-Ogbuafor, Gray and Stead (2016) reported no differences between bottom-up and top-down approaches in a project in Nigeria. The successful projects in Arya Jawi and other faith-based communities appear to be to a considerable extent due to the fact that project participants were motivated by religious principles to a greater extent than their secular counterparts (Ferris, 2005).

The provision of the predominantly technical, agricultural and environmental services by Worku Mulat and his five brothers in Kersole Village was made possible largely because of their technical and scientific education, although the construction of the first Ethiopian Orthodox Tewahedo Church in this village also reveals their religious compassion. The links the four brothers in the diaspora maintained with their Ethiopian home community illustrates a geographical link that has received little attention from researchers.

The operation of the Kersole project will need to be monitored and modified to ensure its sustainability in view of its logistically tenuous management structure. Moreover, because all the projects except the church were implemented by the Mulat brothers primarily for their family, with a relatively small spin-off effect on the whole community, there is a need to transfer more project planning, implementation and resource generation responsibilities to the wider community if full participation and further livelihood improvements are to be achieved. This will prevent selective participation, a major problem in community development (Unite for Sight, 2015).

The sustainability of all three projects appears to be ensured, but for different reasons. The Arya Jawi project has become self-sufficient and is now successfully managed by a faith-based community organization, the new schools in Azena have been integrated into the woreda educational system, and plans are being made by the community and the woreda for taking over the maintenance of the bridge from the NGO. The sustainability of the Kersole project, while ensured for the foreseeable future through the commitment of the Mulat brothers to help their family, may ultimately depend on broader community participation to broaden the support base, as indicated by other studies (Wasilwa, 2015 I deleted Admassu et al., 2003).

The full impacts of the three projects go far beyond the objectives set by the communities as reported here because of spinoff effects of newly introduced infrastructure and services such as schooling. The construction of schools in 
Azena Town and the school sponsorship program in Arya Jawi, for example, promises to benefit not only students but also graduates who become farmers. This is indicated by a study of 14 villages in highland Ethiopia, where schooling contributed significantly to increased grain production (Weir, 1999). The new road in Arya Jawi, built mainly to provide for better access to urban markets and other businesses, promises to increase economic growth and reduce poverty as indicated by other studies (Dercon, Gilligan, Hottenott, \& Woldemariam, 2007). Another example is the creation of jobs through the various projects implemented in Kersole Village, which may reduce outmigration by young people and strengthen the economic base of this community, as indicated by other studies in Africa (Economic Commission for Africa, 2017).

\section{Conclusion}

This first study of the role of academics in community development in Ethiopia and apparently in Africa indicates that committed university-educated individuals can play key roles as leaders and facilitators in planning and implementing a wide range of projects in rural communities. The project in Arya Jawi benefited from the organizational acumen of a senior community leader and his junior relative working within the setting of the local church; six brothers were able to carry out, using their own resources, a number of infrastructure and livelihood projects within a family setting in Kersole; and one professor from Addis Ababa University planned, initiated and facilitated the construction of a bridge and several schools in Azena in consultation with local committees, and with funding from international NGOs. Because the respective academics were natives of these communities and had intimate knowledge of community needs, they were able to identify projects that were relevant and feasible, generating the necessary community participation. The strengths of the various approaches used, the collaboration with local people and organizations, and achievements and difficulties encountered during different stages of the projects are described, making these case studies sources of information for other researchers interested in exploring the potential role of academics in other communities.

\section{Acknowledgements}

The technical and financial assistance provided by family members hailed from Kersole community is acknowledged. The support provided by the Jama Woreda Agricultural Bureau, Kebebew Daka of the Buraka Family Committee, and the Kersole and Arya Jawi communities contributed significantly to the implementation and sustainability of the projects. PiHA, FGCF, and Live Charitable Trust generously supported the bridge and school projects and their staff members, particularly Ato Yehalem Abebe, provided much assistance. Several woreda and zone officials supported the mobilization of the community and special thanks to Getnet Mossie and members of the Azena community for their enthusiastic participation. We also want to thank Ann Byers for editing the final draft.

\section{References}

Adane, M., Mengistie, B., Kloos, H., Medhin, G., \& Mulat, W. (2017). Sanitation facilities, hygienic conditions, and prevalence of acute diarrhea among under-five children in slums of Addis Ababa, Ethiopia: Baseline survey of a longitudinal study. PloS ONE, 12(8). https://doi.org/10.1371/journal.pone.0182783

Adejumobi, S. A. (2005). The history of Ethiopia. Westport, Conn.: Greenwood Press.

Arén, G. (1978). Evangelical pioneers in Ethiopia: Origins of the Evangelical Church Mekane Yesus. Stockholm: Uppsala University.

Baker, L. R. (2018). Prospects and pitfalls of a university-community partnership using Jatropha for sustainable rural development in a Nigerian community. Community Development, 49(1), 50-64.

Berhe, T. G., Tesfahuney, R. G., Desta, G. A., \& L. S. Mekonnen, L. S. (2017). Biogas distribution for rural household sustainability energy supply in Africa. Energy and Policy Research, 4(4), 10-20.

Bishaw, B. (2001). Deforestation and land degradation in the Ethiopian highlands: A strategy for physical recovery. Northeast African Studies, 8(New Series), 7-25.

Bishaw, B., \& Asfaw, Z. (2010). Hydrological and related aspects of deforestation and degradation of woody vegetation. In Y. Berhane, D. Haile Mariam, \& H. Kloos (Eds.), The epidemiology and ecology of health and disease in Ethiopia. (pp. 183-211). Amherst, N.Y: Cambria Press.

Botes, L., \& van Rensburg, D. (2000). Community participation in development: Nine plagues and twelve commandments. Community Development Journal, 35, 41-58.

Cafer, A. M., Willis, M. S., Beyene, S., \& Mamo, M. (2015). Growing healthy families: Household production, food security, and wellbeing in South Wollo, Ethiopia. Culture, Agriculture, Food and Environment, 37(2), 63-73. http://doi.10.1111/cuag.12053 
Chacko, E., \& Gebre, P. (2009). Diaspora investment, motivations and challenges. Paper presented at the International Conference on Diaspora and Development, Washington, DC. Retrieved from http://Siteresources.worldbank.org/INTROSPECTS/Resources/334934

Chelkeba, A. (2011). Impact assessment of the Charities and Societies Law on the growth and programs of non-governmental organizations: a survey of Addis Ababa City Administration, Addis Ababa, Ethiopia. LLM thesis, School of Law, Addis Ababa University. Retrieved from www.academia.edu/NGO _law_in_Ethiopia_and_its_impact

Community outreach activities of African universities. Anonymous. (n.d.). Retrieved from www.pitlanemagazine.com/cultures/community-outreach-activities-of-african-universities

Demissie, B. S., \& Kasie, T. A. (2017). Rural household's vulnerability to poverty in Ethiopia. Journal of Poverty, 21, 528-542. https://doi.org/10.10875549.2017.1348425

Dercon, S., Gilligan, D. O., Hotttonott, J., \& Woldehanna, T. (2007). The impact of roads and agricultural extension on consumption growth and poverty in fifteen Ethiopian villages. Columbia University Libraries, African Studies Working Paper CSAE WPS/2007/01. Retrieved from http://ideas.repec.org/s/oup/ajager.html

Economic Commission for Africa. (2017). African migration: Drivers of migration in Africa. Draft report. Retrieved from https://www.uneca.org/sites/default/files/uploaded-documents/SocialDevelopment/Global -Migration-2017/drivers-of-migration-in-Africa_advance-copy.pdf

Ethiopian Evangelical Church Draft Plan. (2012). Ethiopia Evangelical Church Mekane Yesus Development and Social Services Commission (EECMY-DASSC) Action Plan for Seven Years (2012-2016). Retrieved from http://www.arcworld.org/downloads/Ethiopian-Evangelical-Church-Plan.pdf

Ethiopian Institute of Water Resources (EIWR). (2014). "Outreach," EIWR, Addis Ababa University, 2014. Retrieved from http://www.aau.edu.et/iewr/overview/outreach

FDRE (Federal Democratic Republic of Ethiopia). (2008). Summary and statistical report of the 2007 Population and housing census: Population size by age and sex. Addis Ababa: FDRE, 2008.

Ferris, E. (2008). Faith-based and secular humanitarian organizations. International Review of the Red Cross, 87(858), 311-325. https://icrc.org/eng/assets/files/other/irre_858_ferris.pdf

Fonchingong, C., \& Fonjong, L. N. (2003). The concept of self-reliance in community development initiatives in the Cameroon grassfields. Nordic Journal of African Studies, 12(2), 196-219.

Geith, C., \& Vignare, C. (2013). Agshare open knowledge: Improving rural communities through university student action research. Journal of Asynchronous Learning Networks, 17(2), 11-20.

Henze, P. (1993). Movement toward modernization: A century of progress. In H. Kloos \& Z. A. Zein (Eds.), The ecology of health and disease in Ethiopia (pp. 9-28), Boulder, Co: Westview Press.

Honadle, G., \& VanSant, J. (1985). Implementation for sustainability: Lessons from integrated rural development. West Hartford, Conn., Kumarian Press. https://doi.org/10.1002/pad.4230080312

International Center for Not-for-Profit Law). (2009). NGO law monitor: Ethiopia. http//chilotfiles.worldpress.com/.../08/ngo-law-monitor-Ethiopia.pdf

Ika, L. A. (2012). Project management for development in Africa: Why projects are failing and what can be done about it. Project Management Journal, 43(4), 27-41.

International Initiative for Impact Evaluation (2017). Household and economy-wide impacts of a public works programme in Ethiopia. Retrieved from www.3ieimpact.org/media/filer_public/2017/11/15/sptw-brief.pdf

Kelbessa, W. (2001). Traditional Oromo attitudes towards the environment: An argument for environmentally sound development. Addis Ababa: OSSREA (Organization for Social Science Research in Eastern and Southern Africa).

Kuschminder, K., \& Siegel, M. (2012). Understanding Ethiopian diaspora engagement policy. UNU-Merit Working Paper Series, No. 2011-040, Maastricht, The Netherlands: Maastricht University and United Nations University.

Little, P. D. (2008). Food aid dependency in northeastern Ethiopia: Myth or reality? World Development, 36(5), 860-874. https://doi.10.1016/j.worlddev.207.05.006

Negatu, W. (2004). Reasons for food insecurity of farm households in South Wollo, Ethiopia: Explanations at grassroots. Addis Ababa: Institute of Development Research, Addis Ababa University. 
Negewo, E. N., Ewnetu, Z., \& Tesfaye, Y. (2016). Economic evaluation of forest conserved by local community for carbon sequestration: The case of Humbo Community Assisted Natural Regeneration Afforestation/ Reforestation (A/) Carbon Sequestration Project; SNNPRS, Ethiopia. Low Carbon Economy, 7, 88-105. http://dx.doi.org/10.4236/ice.2016.72009

Okeke-Ogbuafor, N. (2016). A comparative analysis of the role of traditional and modern community-based organizations in promoting community development in Ogoniland, Nigeria. Community Development Journal. https://doi.10.1093/cdj/bsw018/2607768

Ozor, N., \& Nwankwo, N. (2008). The role of local leaders in community development programmes in Ideato Local Government Area of Imo State: Implications for extension policy. Journal of Agricultural Extension, 12(2), 64-75.

Sabbil, A. A., \& Adam, O. H. M. (2015). Factors affecting project sustainability beyond donor's support: The case of Area Development Scheme (ADS) in Umkadada Locality, North Darfur State, Western Sudan. International Journal of Technical Research and Applications, 3(3), 94-101.

Schemm, P. (2016, May 14). They fled Ethiopia amid war and privation: An economic boom is bringing them home. The Washington Post. Retrieved from http://nazret.com/blogindex.php/2016/05/15/they-fled-ethiopia -amid-war

Tecle, T. (1974). Rural development programs in Ethiopia: A review of the Chilalo Agricultural Development Unit, the Wollamo Agricultural Unit, and the Minimum Package Program. Washington, DC: International Bank for Reconstruction and Development.

Tegegne, M., Asefa, M., Tessema, F., \& Kebede, K. (2000). Assessment of the community-based training programme at Jimma University, Ethiopia. Ethiopian Journal of Health Development, 14, 239-252.

Teka, T. (2000). International non-governmental organizations in rural development in Ethiopia: Rhetoric and practice. New York: Peter Lang.

Teketay, D. (2001). Deforestation, wood famine, and environmental degradation in Ethiopia's highland ecosystems: urgent need for action. Northeast African Studies, 8(New Series), 53-76.

Udensi, L. O., Udoh, O. S., Daasi, G. L. K., \& Igbara, F. N. (2012). Community leadership and the challenges of community development in Nigeria: The case of Boki Local Government Area, Cross River State. International Journal of Development and Sustainability, 1, 912-923. Retrieved from www.isdnet.com/ijds

Uhawenimana, T. C. (2012, February 11). Higher education needs to engage in outreach-based research. University World News, No. 236. Retrieved from http://www.universityworldnews.com/article.php?story $=20120822164106621$

Unite for Sight. (2015). Modelu 2: "Nine plagues" of community participation. Global Health \& Innovation Conference, Global Health University. Retrieved from www.unite-for-sight.org/community-development/ course $4 /$ module2

Warden, R. (2014, December 19). Engaged universities contribute to economic development. University World News. Retrieved from http://www.universityworldnews.com/article.php?story=20141119095107901

Wasilwa, C. (2015). Effect of community participation on sustainability of community-based development projects in Kenya. Retrieved from http://www.linkedin.com/pulse/effect.community-participation-sustainability -based-calebwasilwa

Weir, S. (1999). The effect of education on farmer productivity in rural Ethiopia. Working Paper WPS99-7, Center for the Study of African Economics, Oxford University. Retrieved from http://www.researchgate. newpublications/40823735

Wole, D. (1999). The origins, endeavors and demise of the Ethiopian University Service: A look at the evolution of an idea. East African Social Science Research Review, 15(2), 43-63.

World Bank. (2015). ET Productive Safety Nets Project 4 (PSNP 4) (P146883): Implementation Status \& Results Report: Sequence 2. Retrieved from http://documents.world.bank.org/curate/en/2015/09/2504333 productive-safety-nets-project-4-psnp-4-p-146883-implemenation-status-results-reportsequence-02

World Bank. (n.d.). Female headed households (\% of households with female heads). Retrieved from http://www.data.worldbank.org/indicators/SP.HOU.FEMA.ZS 
World Council of Churches (2006). Ethiopian Evangelical Church Mekane Yesus (EEMCY). Retrieved from archieved.oikoumene.org/en/handbook/global-bodies-and-mission-commissions/wcc.html

Yeneabat, M., \& Butterfield, A. K. B. (2012). We can't eat a road:” Asset-based community development and the Gedam Sefer Community Partnership in Ethiopia. Journal of Community Practice, 20(1/2), 134-153.

Zeelen, J. (2012). Universities in Africa: Working on excellence for whom? Reflections on teaching, research, and outreach activities at African universities. International Journal of Higher Education, 1(2), 157-165.

\section{Copyrights}

Copyright for this article is retained by the author(s), with first publication rights granted to the journal.

This is an open-access article distributed under the terms and conditions of the Creative Commons Attribution license (http://creativecommons.org/licenses/by/4.0/). 